\title{
Historical Evolution of Pre-service Training of Primary School Teachers in China since the Founding of the People's Republic of China 70 Years ago
}

\author{
Long Yuhan \\ School of Education, Yangtze University, Jingzhou District, \\ Jingzhou City, Hubei Province, 434023 PRC China.
}

Type of Work: Peer-Reviewed

DOI: http://dx.doi.org/10.21013/jems.v15.n4.p1

\begin{abstract}
How to cite this paper:
Yuhan, L. (2019). Historical Evolution of Pre-service Training of Primary School Teachers in China since the Founding of the People's Republic of China 70 Years ago. IRA International Journal of Education and Multidisciplinary Studies (ISSN 2455-2526), 15(4), 110-114.doi: http://dx.doi.org/10.21013/jems.v15.n4.p1
\end{abstract}

(C) Institute of Research Advances.

This work is licensed under a Creative Commons Attribution-Non Commercial 4.0 International License subject to a proper citation to the publication source of the work.

Disclaimer: The scholarly papers as reviewed and published by the Institute of Research Advances (IRA) are the views and opinions of their respective authors and are not the views or opinions of the IRA. The IRA disclaims of any harm or loss caused due to the published content to any party.

Institute of Research Advances is an institutional publisher member of Publishers International Linking Association Inc. (PILA-CrossRef), USA. The institute is an institutional signatory to the Budapest Open Access Initiative. Hungary advocating the open-access of scientific and scholarly knowledge. The Institute is a registered content provider under Open Access Initiative Protocol for Metadata Harvesting (OAl-PMH).

The journal is indexed \& included in WorldCat Discovery Service (USA), CrossRef Metadata Search (USA), WorldCat (USA), OCLC (USA), Open J-Gate (India), EZB (Germany) Scilit (Switzerland), Airiti (China), Bielefeld Academic Search Engine (BASE) of Bielefeld University, Germany, PKP Index of Simon Fraser University, Canada. 


\section{Abstract}

The main task of developing primary education is to improve the quality of primary school teachers and ensure the quality of primary school teachers. With the continuous development and change of society, so far, primary school teacher education in our country has experienced the stage of the training-oriented secondary normal school; the stage of transformation from secondary normal school to higher normal college and undergraduate course; and the stage of coexistence of higher normal college, undergraduate and master training. Satisfactory progress has been made.

Keywords: 70 years after the founding of the People's Republic of China; primary school teachers; pre-service training; development history

Since the emergence of teacher education, the pre-service training of primary school teachers in our country has gradually changed from the closed type of the old three-level normal school to the open type of the new three-level normal school. In the process of transformation, although primary school teachers' academic qualifications have been gradually improved, they have gradually lost their original characteristics of normal education, and the situation of higher educational qualifications and lower quality has emerged. Therefore, it is necessary to explore the development process of primary school teacher training.

\section{The Stage of Training-oriented Secondary Normal School (1949-1998)}

Since the founding of New China, secondary normal schools have been mainly responsible for the task of training primary school teachers. They have trained a large number of excellent primary school teachers and accumulated rich experience in running schools. According to statistics, since the founding of the People's Republic of China, the number of secondary normal schools has increased from 610 to 875 in 1998, and the number of students has increased from 151750 to $921000^{[1]}$. At the National Conference on Normal Education held by the Ministry of Education in 1980, the author summarized the experience of running secondary normal education over the years and studied the feasible measures for continuing to run secondary normal education well. Since then, in the document "Draft Rules for Secondary Normal Schools (Trial Implementation)" issued by the Ministry of Education, the nature, tasks, system, scale, purpose, curriculum, teaching organization, student management, educational internship and internship, school leadership system of secondary normal schools have been clearly defined. In addition, secondary normal schools attach great importance to the link of educational internship and practice, through which the connection between theory and practice of normal education can be strengthened, so that the trained normal students can have the ability to work independently, and the determination to engage in primary school teaching can be fostered more firmly.

In June 1986, in the Notice on the Adjustment of Teaching Plans in Secondary Normal Schools promulgated by the State Education Commission, it was proposed to unify the teaching of secondary normal schools throughout the country, strengthen the education of cultural knowledge, and gradually put the secondary normal education on the track of teaching-oriented principle. In July 1987, in the Draft Trial Implementation of the Catalogue of Instruments for Science Teaching in Secondary Normal Schools, the teaching requirements and conditions of secondary normal schools were clearly and specifically stipulated. The "Three-year Secondary Normal School Teaching Program (Trial Implementation) promulgated in 1989 broke the single form of compulsory courses in traditional normal schools, increased elective courses, extra-curricular activities, and educational practice courses, and opened up a new pattern of normal education. 
After several years of vigorous development, in 1990, due to the disappearance of preferential treatment policy for secondary teachers and students, the state promoted the level of primary school teachers'academic qualifications; the expansion of universities and high schools led to the decline of the attractiveness of secondary teachers and students; the forced transformation of secondary teachers; the loss of excellent junior middle school graduates ${ }^{[2]}$. Eventually, secondary normal education gradually declined and gradually withdrew from the stage of the history of normal education.

\section{The Training Stage of the Transition from Secondary Normal School to College and Undergraduate (1986-2007)}

With the continuous progress and development of society and economy, society requires that the quality of workers should be constantly improved. It is very difficult for primary school teachers trained in secondary normal schools to meet the needs of social development. Primary school teacher education in our country has begun to transit from secondary normal school to tertiary school, and training primary school teachers at the tertiary level has become the mainstream direction of teacher education. The earliest reform experiment was carried out in Nantong Normal School of Jiangsu Province in 1984. In 1986, Shanghai upgraded two secondary normal schools to higher normal colleges, responsible for training Five-year Primary and kindergarten teachers $^{[3]}$.

After entering the 1990s, the speed of transformation of secondary normal colleges has gradually accelerated. In 1991, the State Education Commission promulgated the Notice on the Training of Primary School Teachers at the Specialized Level, which stipulates that the training of primary school teachers should be conducted on a five-year, three-two-year and two-year trial basis. The curriculum and teaching content should be based on the training specifications of primary school teachers at the specialized level and should be oriented to primary education, highlighting the characteristics of normal education. The Plan of Action for the Revitalization of Education in the 21st Century issued by the Ministry of Education in 1998 put forward that in order to implement the "cross-century gardener project", the qualified areas should strive to upgrade the academic qualifications of full-time primary and junior middle school teachers to the professional and undergraduate levels around 2010 ${ }^{[4]}$. On March 16, 1999, the Ministry of Education issued "Several Opinions on the Layout Adjustment of Teachers'Colleges", requiring the reorganization of teachers' education resources, the adjustment of school layout and the gradual improvement of the focus of the hierarchical structure ${ }^{[5]}$.

Through reform, the number of secondary normal schools in China dropped to 141 in $2010^{[6]}$. Although there are still a certain number of secondary normal schools, they have survived in the name. Most of these schools run $3+2$ Normal College education. It is worth pointing out that compared with normal school students, junior college students have basically achieved the common improvement of their academic qualifications and abilities.

\section{The Coexistence Stage of Training of College, Undergraduate and Master in Normal University} (2007-Now)

In 1997, the Ministry of Education set up a research group on the professional construction of primary school teachers with undergraduate academic qualifications and proposed that the primary education speciality should be included in the scope of general higher education ${ }^{[7]}$. The Ministry of Education actively encourages and supports some qualified normal universities to organize pilot sites for training primary school teachers with 
undergraduate degrees. Subsequently, some normal colleges and universities have set up primary education majors with undergraduate degrees. This means that the major primary education has become a formal major in the higher education system of our country.

In 2002, the "Several Opinions on Strengthening the Training of Primary School Teachers with College Degree or Above" pointed out that we should actively explore the training mode of primary school teachers with College Degree or Above Degree. Recruitment of high school graduates internship for three years and four years of undergraduate education; Recruitment of junior high school graduates, three years in the normal school training, the latter two years in the normal school training of the "three-two subsection system" of specialized education. By the end of 2007, 69 normal universities in China had established undergraduate majors in primary education, and some comprehensive normal universities had begun to recruit and train Master of Education majors in primary education ${ }^{[8]}$. But at this stage, primary school teachers are mainly trained by specialists and undergraduates.

The training mode of primary school teachers with undergraduate degree mainly includes a comprehensive training mode, subject-based training mode, and moderate training mode. The comprehensive training mode does not distinguish between disciplines and emphasizes the training of comprehensive and compound primary school teachers ${ }^{[9]}$; the subject-based training mode is mainly to train full-time teachers of a certain discipline ${ }^{[10]}$; the moderate training mode is based on comprehensive training, but it is appropriate to carry out the subject-based training.

After systematically combing the development process of primary school teachers' education and training in China, it is found that each training stage has its own characteristics and shortcomings, especially the disappeared normal school. Although it has the shortcomings of emphasizing "teacher-training" and neglecting "academic", its rich teaching experience is worth continuing to be inherited and be used. The author believes that we should not neglect or discard the experience and traditional value of secondary normal school education. We should extract the essence and discard the dross, preserve the essence that is worth learning, and integrate into the training of modern primary school teachers, so as to jointly promote the development of our primary school teachers' training.

\section{References:}

[1]. Gao Fazhao. Research on the History, Current Situation and Problems of Pre-service Training of Primary School Teachers in China [D].Ji Nan: Shandong Normal University, 2005, 34-37.

[2]. Liu Xiufeng. Glory and Decay: Retrospect and Reflection on the Development of Secondary Normal Education [J]. Research on Educational Development, 2017:56-62.

[3]. Mei Xinlin. 30 Years of Teacher Education in China [M].Beijing: China Social Science Press, 2008:272.

[4]. He Dongsheng. Important Educational Documents of the People's Republic of China (1998-2002)[M].Hai Kou: Hainan Press.

[5]. Jin Yinfeng. The Development Course and Model Change of Primary School Teacher Training in China [J]. Contemporary Educational Science, 2018(4):73-76.

[6]. Yu Xingguo. Research on Trends, Factors and Strategies of Teacher Education Development [J]. Research on Teacher Education, 2010,(6):15-19.

[7]. Ma Yunpeng, Xie Shu. Research on the Training Model of Undergraduate Major in Primary Education [J]. Research on Higher Education, 2008, 29(4):73-78.

[8]. Xu Wenbin, Wang Aiju. Current Situation and Future Construction of Undergraduate Major in Primary Education in Normal Universities [J]. Courses, textbooks and teaching methods, 2007,(12):75-80.

[9]. Qin Qixuan. Exploration on the Training Model of Undergraduate Primary Education Professionals [J]. Journal of Jimei University: Educational Science Press, 2012, 13(3):1-5.

[10].Zhang Cheng. Research on the Training Program of Primary Education Major with Bachelor's Degree [D]. Hangzhou: Hangzhou Normal University, 2011. 